at $B J 6.129$ (discussed above) a group of brigands can have its tyrant, so too here tyrants have their bands of brigands.

Josephus' 'tyrants' and 'brigands' refer to two entirely separate entities or classes of people: the former exclusively to the revolt's ringleaders; the latter to their common followers and foot soldiers. This distinction drew a parallel between the archetypal Roman tyrant who, more often than not, arose from within the ruling aristocracy, and his Jewish counterparts. In both cases, the 'tyrant' was of an entirely different class from his rank-and-file followers, most of whom were of lower social rank. Whether Judaea's rebel leaders were in fact renegade aristocrats is immaterial to this argument. ${ }^{13}$ Josephus was communicating to his Roman contemporaries that his Jewish 'tyrants' were akin to their own. In so doing, he was placing the war between Rome and Judaea in the context not of a clash between warring peoples or ideologies but of a shared domestic socio-political malady that had, intermittently and with severe ramifications, plagued Rome itself, especially in the century leading up to, and including, the times of Josephus' Roman contemporaries.

The Hebrew University of Jerusalem

STEVEN BEN-YISHAI

steve.benyishai@mail.huji.ac.il

doi:10.1017/S0009838821000689

(C) The Author(s), 2021. Published by Cambridge University Press on behalf of The Classical Association.

\title{
MARTIAL AND THE DOCTORS: OPHTHALMOLOGY AND UVULECTOMY IN EPIGRAM 10.56*
}

\begin{abstract}
This short note attempts to shed light on some of the surgical procedures referred to in Martial's epigram 10.56 by consulting pertinent Graeco-Roman medical texts. A fuller understanding of one such intervention (treatment of infected/inflamed uvula) supports Martial's text as transmitted.
\end{abstract}

Keywords: doctors; blepharitis; cauterization; uvula; caustics

totis, Galle, iubes tibi me seruire diebus et per Auentinum ter quarter ire tuum. eximit aut reficit dentem Cascellius aegrum, infestos oculis uris, Hygine, pilos; non secat et tollit stillantem Fannius uuam, tristia seruorum stigmata delet Eros: enterocelarum fertur Podalirius Hermes: qui sanet ruptos dic mihi, Galle, quis est?

Of the various professions cited in his Epigrams, Martial dwells prominently on healers. In all, Epigrams cite, or imply, a medicus, medica, clinicus or chirurgus around twenty

${ }^{13}$ M. Goodman, The Ruling Class of Judaea: The Origins of the Jewish Revolt against Rome A.D. 66-70 (Cambridge, 1987), 201-6.

* I thank the anonymous referee for valuable suggestions for improvement. 
times, some by name, others left anonymous. ${ }^{1}$ Of the eleven books, all, save for Book 3 , refer to a doctor at least once. In a few cases, several are named $(6.70,11.60)$ and, in one remarkable instance, five. As it happens, that is the very epigram of interest here.

Martial opens 10.56 by complaining that Gallus keeps him constantly moving about the Aventine in service. To heighten the misery of his situation, Martial singles out five specialists who treat various maladies. Unfortunately, there is no practitioner for patients who, like Martial, are ruptos ('broken', 'ruptured', 'strained to the limit', 8).

I propose, using Graeco-Roman medical texts, to shed light on the activities of two of the practitioners named, because, up to this point, commentators are uncertain precisely what it is Martial says they do. First is Hyginus, who burns hairs on infected eyes: infestos oculis uris, Hygine, pilos (4). ' The nature of the condition treated 'seems', in the eyes of the most recent commentator, 'rather peculiar and is not readily identifiable' ${ }^{3}$ In fact, Celsus (7.7.8B Marx) describes just such a malady when, without specifically naming it, he refers to irritating eyelashes that may cause the eyelid to turn in. Most likely, he means conditions we now call trichiasis and blepharitis, ${ }^{4}$ diseases characterized by inflammation of the hair follicles along the eyelid and its inversion. To treat these irritating eyelashes, Celsus recommends cauterizing the roots of the offending hairs with a 'fired slender iron needle shaped like the head of a spear/lance': tenuis acus ferrea ad similitudinem hastae lata. It is likely that such a cauterizing procedure lurks behind the term uris, as applied to Hyginus.

uris could reflect application of caustics as well. A later surgical authority, Paul of Aegina, attests to a caustic recipe including quicklime mixed with urine of a youth, as a treatment for trichiasis (6.9 Heiberg). However, because of the risk of injury to the patient's eye, he disapproves of its use, maintaining that use of caustics on eyes

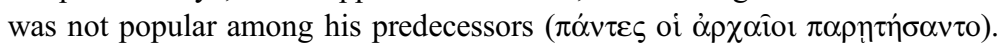

The other specialist of interest is Fannius, an expert in treating diseased uvula, the appendage that hangs down in the back of the throat between the tonsils. Fannius, Martial asserts, does not cut out the uvula but still removes it: non secat et tollit stillantem Fannius uuam (5). ${ }^{5}$ It seems to have puzzled modern editors and commentators how Fannius removes the uvula without cutting it, starting with Alan Ker: 'How you can remove a suppurating uvula without cutting it I don't know, and I doubt if even Fannius could have told us. Nor, if you could, would this be Martial's Latin for it.' 6 On this account Ker proposed emending non secat to insecat ('cut into') or consecat ('cuts off'). Ker's scepticism has been accepted and repeated by Shackleton Bailey ${ }^{7}$ and,

\footnotetext{
${ }^{1}$ References are conveniently collected by D.R. Shackleton Bailey in his Loeb edition (Martial, Epigrams, 3 vols. [Cambridge, Mass. and London, 1993], 3.327, s.v. 'Doctor'). As medicine was basically a Greek profession, most of Martial's doctors have Greek, probably fictive, names. Typically for a Roman, his attitude toward them tilts to the negative.

${ }^{2}$ Of the others, Hermes is joined at 11.84 by Alcon (also 6.70), another surgeon dealing with hernias; and, in addition to Hyginus, we meet another ophthalmicus (anonymous) at 8.74.

${ }^{3}$ C.C.M. Francis, 'Martial Epigrammata, Book X: a commentary' (Diss., University of Otago, New Zealand, 2007), 349, available online at http://hdl.handle.net/10523/8106.

${ }^{4}$ See ss.vv. in Taber's Cyclopedic Medical Dictionary, ed. C.L. Thomas (Philadelphia, 2021 ${ }^{24}$ ).

${ }^{5}$ Uvulectomy is still performed for conditions such as sleep apnoea and in folk medicine; see A.A. Adoga and T.L. Nimkur, 'The traditionally amputated uvula amongst Nigerians: still an ongoing practice', ISRN Otolaryngology (Published online 22 November 2011, doi: 10.5402/2011/704924. PMCID: PMC3658569. PMID: 23724258. Free PMC Article).

${ }^{6}$ A. Ker, 'Some explanations and emendations of Martial', CQ 44 (1950), 12-24. Ludwig Friedlaender was untroubled by Martial's Latin in his seminal Leipzig edition of 1886, vol. 2, 141.

${ }^{7}$ Shackleton Bailey (n. 1), 2.376-7.
} 
most recently, by Francis, ${ }^{8}$ both of whom also entertain, though they do not adopt, his emendation.

Actually, the text is perfectly clear as stands. In Martial's time, in addition to amputation, the uvula might be treated with medications. This, in fact, was the preferred method. Centuries before, the author of the Hippocratic Prognostikon (23 Jones, repeated by Cassius Felix 35.1) had emphasized the danger of amputating or puncturing an infected uvula and, though he allowed for these procedures, preferred reduction by another means left unexpressed. ${ }^{9}$ The other means, the application of caustic medication, appears in two contemporaries: Celsus, who also remarked on the danger of amputation $(6.14,7.12)$, and Pliny the Elder (HN 34.109). Their recipes included oak gall, split alum (galla uel alumine scissili) and copper scale and flower (squama et flos aeris).${ }^{10}$ Notable in his recipe is Pliny's use of language similar to Martial's: et uuas oris ... tollit et tonsillas. Clearly this safer method is the one used by Dr Fannius in 10.56; hence no cutting is involved (non secat) and no emendation of Martial's Latin is required.

Fannius, if he followed Celsus' directives, will have applied caustic by means of a spoon (cocleario). At some point a special, pliers-like forceps with spoon-shaped

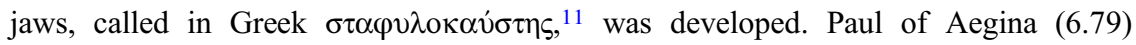
describes its actual operation. In cases where the patient fears the knife, or there is danger of haemorrhage, the $\sigma \tau \alpha \varphi v \lambda$ oк $\alpha$ vin $\varsigma$ was loaded with caustics, clamped onto the uvula and kept in place until the offending part was burned away. The same instrument was used on haemorrhoids, in which case it went by the name

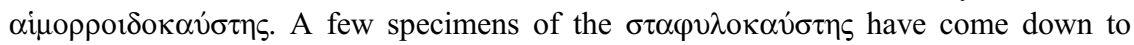
us. ${ }^{12}$ Paul, of course, is a very late source (seventh century c.E.). However, he digested the writings of Imperial surgical authorities such as Leonides, Antyllus and Heliodorus, all of them contemporaries of Fannius and Martial. ${ }^{13}$

In light of the points made, a more accurate (if inelegant) rendering of the epigram might read:

Gallus, you order me to be at your beck and call the whole day and to cross over your Aventine three or four times. Cascellius pulls or repairs an aching tooth; you, Hyginus, cauterize hairs that trouble eyes; Fannius removes an inflamed uvula without amputation; Eros obliterates the miserable brands of slaves; ${ }^{14}$ people say Hermes is the Podalirius of hernias. Tell me, Gallus, who cures people who are ruptured/broken down?

\footnotetext{
${ }^{8}$ Francis (n. 3), 350.

9 The Hippocratic author of Affections 4 (Potter) prescribes cupping or lancing with a knife.

${ }^{10}$ For other compounds with similar ingredients for a diseased uvula, see Scribonius Largus 64-5 (Sconocchia).

${ }^{11}$ The instrument may also have been called $\sigma \tau \alpha \varphi v \lambda \varepsilon \pi \alpha \dot{\rho} \tau \eta \varsigma$, if that was not just another term for the spoon used. See L.J. Bliquez, The Tools of Asclepius: Surgical Instruments in Greek and Roman Times (Leiden, 2015), 146, 246-7.

12 See R. Jackson, 'Staphylagra, staphylocaustes, uvulectomy and haemorrhoidectomy: the Roman instruments and operations', in A. Krug (ed.), From Epidaurus to Salerno, Symposium held at the European University Centre for Cultural Heritage, Ravello, April, 1990=PACT, Journal of the Centro Universitario Europeo per i Beni Culturali 34 (1992), 167-85. For recovery of the most recent specimen, see R. Jackson, 'Lo strumentario chirurgico della domus rimanese / The surgical instrumentation of the Rimini Domus', in S. De Carolis (ed.), Ars Medica. I Ferri del mestiere. La domus 'del chirurgo' di Rimini e la chirurgia nell'antica Roma (Rimini, 2009), 73-91, at 85, 89 and fig. 2.21 and pl. facing 78.

${ }^{13}$ For these important figures in Graeco-Roman surgery, see ss.vv. P. Keyser, G. Irby Massie (edd.), The Encyclopedia of Ancient Natural Scientists (London and New York, 2008).

${ }_{14}$ 'Slaves' is an emendation. See Francis (n. 3), 350 for details.
} 
Obviously, Martial was sufficiently interested in the doings of doctors to incorporate their treatments into his verses. However much he actually knew about medicine, he knew that diseased eyes were treated with cauterization and that a stillans uиa (and perhaps eyes too) was treated with caustics. Being a Roman poet, however, he preferred brevity and allusion to full and precise terminology in 10.56. In doing so, he surely assumed that his contemporary audience would understand his indirect phrasing. As this study shows, that is not always the case with his modern readers. For us, a proper understanding of 10.56 requires recourse to Graeco-Roman medical literature not just to comprehend fully the surgeries at issue in this epigram but also to restore confidence in Martial's Latin.

University of Washington, Seattle

LAWRENCE J. BLIQUEZ

lbliquez@uw.edu

doi:10.1017/S0009838821000641 